\title{
STUDIES IN THEACEAE. IV NEW AND NOTEWORTHY SPECIES OF EURYA
}

\author{
Clarence E. Kobuski
}

Since the publication of the synopsis of "Eurya, Subgenera Euryodes and Penteurya" in $1937,{ }^{1}$ several new species have come to the attention of the author making a supplementary paper necessary. Besides the new species, other noteworthy recently described species and nomenclatorial notes are included. All specimens cited in this study are to be found in the herbarium of the Arnold Arboretum of Harvard University unless otherwise designated. These borrowed specimens are cited under the abbreviations NY $=$ Herbarium of the New York Botanical Garden, New York, and SY $=$ Herbarium of the Botanical Institute, Sun Yatsen University, Canton, China.

Eurya alata, spec. nov.

Frutex glaberrimus $2 \mathrm{~m}$. altus, ramulis alatis, alis ad $1 \mathrm{~mm}$. latis; foliis glaberrimis coriaceis lineari-lanceolatis $6-8 \mathrm{~cm}$. longis et $1.5-2.5$ $\mathrm{cm}$. latis, apice obtusis retusisque, basi cuneatis, supra viridibus, subtus luteo-viridibus, margine serrulatis, petiolis $2-3 \mathrm{~mm}$. longis; floribus femineis axillaribus 2-3 aggregatim dispositis, pedicellis $2 \mathrm{~mm}$. longis glabris, sepalis 5 imbricatis subrotundatis apice obtusis emarginatis, basi plus minusve contractis, petalis 5 albidis basi plus minusve connatis oblongo-obovatis $2-2.5 \mathrm{~mm}$. longis et $0.5-1.0 \mathrm{~mm}$. latis, ovario glabro conico-globoso, stylo brevi $\pm 1 \mathrm{~mm}$. longo 3-fido, ovario ignoto.

Kwangtung: Pan-Ling Tsze, Pei-Koong, North River, in dense woods, W. Y. Chun 5924, Dec. 25, 1927 (shrub 2 m. with white flowers).

An interesting feature of this species is the outstanding winged condition on the very young branchlets with wings as much as $1 \mathrm{~mm}$. long making the branchlets appear almost quadrangular. In the older branchlets, the wings are reduced to pronounced ridges which seem to zigzag along the stem. Eurya alata because of the texture, veining and symmetry of its leaves, resembles E. glaberrima Hayata from Formosa. However, it can be separated from the latter by its winged stem, longer style and delicate corolla. In E. glaberrima, according to Hayata, the ${ }^{1}$ Kobuski in Ann. Missouri Bot. Garden, $25: 299-359.1937$. 
style, being only $0.25 \mathrm{~mm}$. long, is one of the shortest in the genus. In E. alata the style measures $\pm 1 \mathrm{~mm}$. in the flower.

Eurya Brassii, spec. nov.

Frutex prostratus vel adscendens (ex collectore), ramulis pubescentibus; foliis dense dispositis distichis glabris coriaceis obovatis vel ovatis $1-2 \mathrm{~cm}$. longis et $0.7-1.2 \mathrm{~cm}$. latis, apice obtusis retusis, basi cuneatis, margine serrulatis revolutis, venis supra profunde impressis reticulatis, petiolis $1-1.5 \mathrm{~mm}$. longis; floribus pistillatis axillaribus singularibus vel binis, pedicellis ca. $1.5 \mathrm{~mm}$. longis, bracteis sepaloideis, sepalis 5 inaequalibus ca. $2 \mathrm{~mm}$. longis et $1.5 \mathrm{~mm}$. latis, margine glandulosis, petalis 5 albidis breve connatis, obtusis $3 \mathrm{~mm}$. longis et $1.0-1.5 \mathrm{~mm}$. latis, ovario ovato ca. $2 \mathrm{~mm}$. longo et $1.25 \mathrm{~mm}$. lato, stylo ca. $0.5 \mathrm{~mm}$. longo tripartito, floribus masculis axillaribus singularibus vel binis, pedicellis ca. $1 \mathrm{~mm}$. longis, bracteis sepaloideis, sepalis 5 inaequalibus $2-3 \mathrm{~mm}$. longis et 1-2 mm. latis, margine glandulosis, petalis 5 albidis breviter connatis obovatis, $3-4 \mathrm{~mm}$. longis et $3 \mathrm{~mm}$. latis, staminibus $8-13$, filamentis $2 \mathrm{~mm}$. breviter connatis, antheris $1 \mathrm{~mm}$., ovario rudimentario; fructu maturo ignoto.

PAPUA: Central Division, Wharton Range, Murray Pass, grassland ridge crests, alt. 2840 m., L. J. Brass 4185 \& (TYPE), June-Sept. 1933 (common prostrate or ascending shrub often rooting from branches; corolla white; fruit dark blue).- Central Division, Mt. Albert Edward, in low thickets on summits of low ridges on grasslands, alt. $3680 \mathrm{~m}$., L. J. Brass 4499 o May-July 1933 (common, low, dense-foliaged shrub with white flowers).

Eurya albiflora White is one of the closest relatives of $E$. Brassii. Both species have small $(1-2 \mathrm{~cm}$. long) distichous coriaceous leaves with nerves deeply impressed on the upper surface. However, White's species is a shrub or small tree up to $6 \mathrm{~m}$., while E. Brassii, according to the collector, is a prostrate or ascending shrub with a tendency to root from the branches. Also in E. albiflora the branchlets and underside of the leaves are densely pubescent with long brown hairs while in E. Brassii the branchlets except for the very young growth are quite glabrous and the leaves are always glabrous.

Another relative is E. Hellwigii Lauterbach. In Lauterbach's species, the leaves are usually $3 \mathrm{~cm}$. or over in length and about $2 \mathrm{~cm}$. wide and have up to nine pair of veins. The habit is that of a tree $(3-5 \mathrm{~m}$. $)$. In E. Brassii the leaves are not only distinctly smaller but there are hardly ever more than five or six pair of veins. 
Eurya brevistyla, spec. nov.

Ramuli glabri subalati brunnei vel griseo-brunnei; foliis coriaceis glabris obovatis vel ellipticis $4.0-6.5 \mathrm{~cm}$. longis et $1.8-2.5 \mathrm{~cm}$. latis, apice acuminatis, basi cuneatis, margine serrulatis, petiolo $3.5 \mathrm{~mm}$. longo, glabro; floribus ignotis; fructibus axillaribus globosis vel subglobosis glabris ca. $5 \mathrm{~mm}$. longis et $4-5 \mathrm{~mm}$. latis, pedicello ca. $1.5 \mathrm{~mm}$. longo glabro, bracteis 3 inaequalibus glabris sepaloideis minute apiculatis, sepalis 5 inaequalibus concavis glabris ca. $2.0 \mathrm{~mm}$. longis orbicularibus vel suborbicularibus, margine papyraceis, stylo tripartito brevissimo ca. $0.25 \mathrm{~mm}$. longo.

Szechuan: Ma-pien Hsien, F. T. Wang 23083, May 29, 1931.

The very short style $(0.25 \mathrm{~mm}$. $)$ is a most unusual character for this genus, especially in China. It is sufficient to separate the species from all other glabrous Chinese species. The spreading stigmas are longer than the style. There were no flowers on the specimen. Eurya brevistyla can be separated from $E$. nitida its nearest Chinese relative by the short style, the obovate leaves and the short pedicels of the fruit.

Eurya cavinervis Vesque in Bull. Soc. Bot. France, 42: 158. 1895.

Eurya Handeliana Kobuski in Ann. Missouri Bot. Gard. 25: 309. 1937.

Eurya aurescens sensu Handel-Mazzetti, Symb. Sin. 7: 400. 1931, quoad descript. excl. syn.; non Eurya japonica Thunberg var. aurescens Rehder \& Wilson.

India: Sikkim, J. D. Hooker in 1859 (type in Mus. d'Hist. Nat. Paris, fragment \& photo. AA).- Burma, between Sadon and the Yunnan-Chinese border at Changtifang and Kambaiti, alt. 2750 m., J. F. Rock 7046, Nov. 1922 (shrub 5-8 ft. in moss forest).- in thickets, Fort Hertz, Hkamti Plain, alt. 360 m., F. Kingdon Ward 9060, Dec. 23, 1930 (bushy evergreen with white flowers).

China. Y u n n a n : exact locality lacking, G. Forrest 15692 (holotype of E. Handeliana).- G. Forrest 8922, 8940, 11944, 17519, 21537.- H. Handel-Mazzetti 8724.-C. Schneider 2488, 2793.-J. F. Rock 3157, 8066.-C.Wang 63268, 67060, 67441, 67497, 72041, 72044, 72413.

Eurya cavinervis has remained in obscurity since its publication by Vesque in 1895. Recently, a leaf specimen of the type (Hooker, Sikkim, collected in 1895) was obtained from the Herb. Mus. Paris and it proves to be identical with the species described by me in 1937 as E. Handeliana. The deeply impressed veins on the dorsal surface of the shining coriaceous leaves, together with the leaf size are outstanding features of the species not to be mistaken for any other species of Eurya. 
Eurya cavinervis Vesque var. strigillosa (Handel-Mazzetti), comb. nov.

Eurya nitida Korthals var. strigillosa Handel-Mazzetti, Symb. Sin. 7: 400. 1931.

YUNNAN: in dense mixed forest near the town Hsiangschuiho, between Dali [Talifu] and Lidjiang [Likiang], alt. 2750 m., H. Handel-Mazzetti 6453 (ISO-Holotype of. E. nitida var. strigillosa, SY).-C. Wang 63677, 66749. Szechuan: in forest, Mt. Omei, alt. 2400 m., T. T. Yü 480, April 21, 1932 (shrub $5 \mathrm{ft}$. with white flowers and leaves dark green above).- Science Institute of West China 3793 in 1932.

Shining coriaceous dark-green leaves with deeply impressed or channeled veins on the upper surface and raised on the under surface are the characters which ally this variety to $E$. cavinervis rather than $E$. nitida as Handel-Mazzetti had thought. The pubescent character of stem and flower-parts, together with the terete stem, are features which separate it from its species, E. cavinervis.

Eurya chuekiangensis $\mathrm{Hu}$ in Bull. Fan Mem. Inst. Biol., Bot. Ser. 8: 147. 1938 .

Northwestern Yunnan: in forest, Bar-Ru-La, Salween-ChueKiang Divide, alt. 3000 m., C. Wang 67407 Isotype, Oct. 1935 (bushy shrub, $5 \mathrm{ft}$. high with greenish black fruit).

This species is glabrous throughout even to the terminal buds. Unusual features are the very short style $(0.25-0.75 \mathrm{~mm}$.) and the conicorostrate fruit. The latter character is found only occasionally in this genus. Most species are characterized by distinctly globose fruit. As in most perfectly glabrous species, the young branchlets are winged, however, only slightly so in this species.

Eurya dasyclados, spec. nov.

Frutex $1 \mathrm{~m}$. minusve altus, ramulis crassis, teretibus ferrugineo-pilosis; foliis coriaceis rigidis oblongo-ovatis $7-10 \mathrm{~cm}$. longis et $2.5-3.5 \mathrm{~cm}$. latis, basi subrotundatis subcordatis vel cuneatis, apice obtuse acuminatis, supra flavo-viridibus, venis utrinque elevatis, reticulatis, costa subtus pilosis, margine glanduloso-serrulatis revolutis, petiolis crassis parvis 3 $\mathrm{mm}$. minusve longis dense pilosis; floribus pistillatis 3-4 axillaribus subsessilibus vel pedicellis $1 \mathrm{~mm}$. longis, bracteis sepaloideis inaequalibus pilosis, sepalis 5 imbricatis inaequalibus concavis obtusis ca. $1.5 \mathrm{~mm}$. longis sparse pilosis, petalis $5 \mathrm{ca} .2 \mathrm{~mm}$. longis acuminatis, basi adnatis, $0.75 \mathrm{~mm}$. latis, apice $0.25 \mathrm{~mm}$. latis, ovario $2 \mathrm{~mm}$. longo, globoso, glabro, stylo tripartito, $1 \mathrm{~mm}$. longo, ad basim libero; floribus masculis ignotis; fructibus subglobosis, glabris, $4 \mathrm{~mm}$. longis, nigrescentibus. 
Kwangsi: Tong Shan (along Kwangtung border), near Sap-luk Po village, Waitsap District, W. T. Tsang 22790, Type, Sept. 15, 1933 (fairly common; dry sandy soil, silt; scattered shrubs $2 \mathrm{ft}$. high; fruit dark blue). Kwangtung: Sam Kok Shan, Tsungfa-Lungmoon Districts, W. T. Tsang 20431, May 11, 1932 (roadside, dry place; shrub $1 \mathrm{~m}$. tall with black fruit).- Sam Kok Shan, Cheung Uk Village, Ts'ung-hwa (Tsung-fa) District, W.T. Tsang 24846, Mar. 1-16, 1935 (abundant; thicket, three feet high; fruit black).- Chaochow District, N. K. Chun 42631, April 5-May 1, 1931 (shrub in woods).

This species is characterized by thick sturdy terete branches covered with a dense ferruginous pilose pubescence for the first year's growth and dense patchy black pilose pubescence for the second and third year's growth. Its nearest relative, the recently described E. rugosa $\mathrm{Hu}$ has the same pubescence for the initial year's growth, after which it becomes glabrescent. Also, the branchlets appear terete for the first year in E. rugosa, but in the second year appear, as $\mathrm{Hu}$ puts it, somewhat winged.

The leaves are coriaceous, rigid, oblong-ovate, $7-10 \mathrm{~cm}$. long and $2.5-3.5 \mathrm{~cm}$. wide and are yellowish or metallic green in color. The venation presents a most interesting character. At first glance, it appears that the veins are impressed on the upper surface. This is caused by successive depressions in the leaves (at least, in the dried state) at each primary lateral vein. However, on close observation one finds that the veins, even to the secondary and cross-veins, are distinctly raised on both surfaces. In E. rugosa the veins are deeply impressed, like channels on both surfaces.

The same pilose pubescence of the very young growth is sparse on the lower surface, especially along the midrib. In the type specimen (fruiting) the calyx, especially along the central line, the bracts and pedicels are covered with dense ferruginous hairs. This is less noticeable in the flowering specimen from Kwangtung.

The corolla-lobes are very narrow in comparison with those of other species of Eurya and taper from $0.75 \mathrm{~mm}$. at the base where they are adnate for $1 \mathrm{~mm}$. to $0.25 \mathrm{~mm}$. near the acuminate apex.

The ovary and fruit are both glabrous. In E. rugosa the ovary is not known. However, in Hu's species the fruit resembles that of E. trichocarpa Korthals in being glabrescent and in both species only the presence of occasional hairs show that the fruit was once pubescent. When a flowering pistillate specimen is eventually collected, the ovary probably will be covered with a dense hoary pubescence like that of E. trichocarpa in flowering condition.

Eurya dasyclados, to date, is confined to Kwangsi (along the Kwang- 
tung border) and Kwangtung, while E. rugosa $\mathrm{Hu}$ is found in Szechuan.

\section{Eurya Huiana, spec. nov.}

Arbor vel frutex, 2-7 m., ramulis pubescentibus teretibus rubrobrunneis; foliis coriaceis glabris raro costis puberulentis ellipticis vel oblongo-ellipticis vel oblongo-obovatis $6-8.5 \mathrm{~cm}$. longis et $2.5-3 \mathrm{~cm}$. latis, basi cuneatis, apice acuminatis, supra nitide viridibus, subtus pallide viridibus, margine glanduloso- serrulatis, venis subobscuris, petiolis ca. 5 $\mathrm{mm}$. longis glabris; floribus femineis masculisque ignotis; fructibus nigrescentibus globosis glabris ca. $5 \mathrm{~mm}$. diam. pedicellis ca. $2 \mathrm{~mm}$. longis glabris bracteis 2 sepaloideis glabris, sepalis 5 imbricatis inaequalibus glabris $2 \mathrm{~mm}$. longis et $1.5 \mathrm{~mm}$. latis subrotundatis, stylo ca. $2 \mathrm{~mm}$. longo tripartito ad $1 \mathrm{~mm}$. supra basim.

Kweichow: on slope in forest, Miao Wang, Kiangkou Hsien, alt. 600 m., A. N. Steward, C. Y. Chiao \& H. C. Cheo 569, type AA, IsoTYPE NY, September 27, 1931 (shrub 2 m. with black fruit).- In open, Hei-shui-chee, Shih tsien san District, Y. Tsiang 4173, in 1930 (small tree $1 \mathrm{~m}$.; leaves green above, pale green beneath).- In densely shaded mixed woods, Wai-ho, Kweiting, alt. 600 m., Y. Tsiang 5604, 5609, July 6, 1930 (shrub, 3 m.; leaves lustrous green above, light green below; fruit green) (AA, NY, SY).- In light woods, foot of Vanchingshan, Kiangkow, alt. 450 m., Y. Tsiang 7491, 7498, Dec. 8, 1930 (small tree $4 \mathrm{~m}$; ; leaves coriaceous, deep lustrous green above, light green below; fruit black) (AA, NY).- In densely shaded ravine, Vanchingshan, Yinkiang, alt. 400-500 m., Y. Tsiang 7728, Dec. 19, 1930 (tree 8 m. with leaves deep lustrous green above, light green below; fruit black).- In dense woods, Vanchingshan, Yinkiang, alt. 600 m., Y. Tsiang 7824 Dec. 25, 1930 (small tree $7 \mathrm{~m}$; leaves deep sublustrous green above, light green below; fruit black) (AA, NY).

Hunan: shady slope, Ma-Ling-Tung, Sinning Hsien, alt. 650 m., C. S. Fan \& Y. Y. Li 585, Oct. 9, 1935 (shrub 3 m.; fruit becoming black when ripe).

Most workers of this genus have identified this species with E. nitida Korthals. In general appearance there is a great resemblance between the two species. However, E. Huiana has pubescent leaf buds, young branchlets and occasionally puberulent midribs, which immediately separate it from the strictly glabrous $E$. nitida. The stems of this newly described species are terete in contrast to the winged stems of E. nitida.

Some of the Tsiang specimens, especially 5604, 5609, 7491 and 7498 have leaves larger than those described from the type. These specimens have leaves $7-10.5 \mathrm{~cm}$. long and $2.5-4.8 \mathrm{~cm}$. wide. On the other hand, 
Tsiang 4173, 7824, 7728 and Fan $\mathcal{E}$ Li 585 have leaves corresponding in size to those of the description.

Unfortunately all the specimens cited are fruiting specimens, so that it is impossible to give a description of the flowers at this time.

It is a pleasure to name this distinct species in honor of Professor Hsen $\mathrm{Hsu} \mathrm{Hu}$, the Chinese botanist who not only has contributed much to the knowledge of Chinese Theaceae but has also been an inspiration to many students of botany in China.

\section{Eurya impressinervis, spec. nov.}

Frutex vel arbor parva glabra, ramulis prominenter alatis glabris; foliis membranaceis glabris ovatis (vel obovatis) $7-11 \mathrm{~cm}$. longis et 2-3 $\mathrm{cm}$. latis, basi cuneatis, apice acuminatis margine serrulatis, nervis supra impressis, subtus acute elevatis, petiolo $2-5 \mathrm{~cm}$. longo glabro; floribus masculis in axillis foliorum solitariis vel binis ut videtur, pedicellis glabris $2.0-2.5 \mathrm{~mm}$. longis, bracteis sepaloideis, sepalis 5 imbricatis inaequalibus suborbicularibus concavis apiculatis margine glandulosis, petalis 5 basi paulo adnatis obovatis $5 \mathrm{~mm}$. longis et $1.5-2.5 \mathrm{~mm}$. latis, staminibus 15 , filamentis ca. $2 \mathrm{~mm}$. longis, antheris lobatis $2 \mathrm{~mm}$. longis, ovario rudimentario; floribus femineis $2-4$ in axillis foliorum, pedicellis glabris ca. $2.5 \mathrm{~mm}$. longis, bracteis sepaloideis, sepalis 5 imbricatis inaequalibus 1.25 $\mathrm{mm}$. longis, apice obtusis glanduloso-apiculatis, petalis 5 basi paulo connatis, linearibus, apice obtusis retusis ca. $3.25 \mathrm{~mm}$. longis et ca. $1 \mathrm{~mm}$. latis; ovario ovato $1.5 \mathrm{~mm}$. longo et $0.75 \mathrm{~mm}$. lato, stylo $1.75 \mathrm{~mm}$. longo tripartito, stigmatibus 3 ; fructibus immaturis globosis ca. $3 \mathrm{~mm}$. longis latisque, pedicellis $3 \mathrm{~mm}$. longis.

KwANGsi: exact locality and date lacking, C. Wang 40569 TYPE, 40504, 83567, 39482.- Virgin forest, Lao Shan, Loh Hoh Tsuen, Lin Yuin Hsien, alt. 1800 m., A. N. Steward \& H. C. Cheo 418, May 16, 1933 (shrub 5 m. high) (AA, NY).- In forest, Chu Feng Shan, 30 li s.w. of Shan Fang, N. Luchen, alt. 725 m., R. C. Ching 5827 (rare tree $6 \mathrm{~m}$. high; light shining green leaves with impressed nerves above) (NY, SY).- Locality lacking, R. C. Ching 5981, June 14, 1928 (SY).

The outstanding characters of this species are the membranaceous leaves and the depressed venation on the upper leaf surface. The veins on the lower surface are sharply raised and light in color. Depressed venation, even to a greater degree, is found in other species such as E. cavinervis and E. Metcalfiana. However, in both these latter species, the leaves are very coriaceous. The winged condition of the branchlets in E. impressinervis is more pronounced than is usually found in the genus. 
This species, so far as is known, is confined to Kwangsi. Unfortunately, the field notes for the C. Wang - Kwangsi collection, which includes the type, are not available at present, but the data concerning the exact locality, date of collection and miscellaneous notes pertaining to the specimens will be completed as soon as the notes arrive.

Eurya lanciformis, spec. nov.

Arbor $10 \mathrm{~m}$. (ex collectore), ramulis alatis cinereis glabris, innovationibus leviter pubescentibus; foliis coriaceis glabris lanceolatis vel oblongo-ovatis, supra nitido-viridibus subtus pallido-viridibus, apice acuminatis, basi cuneatis, margine undulatis, $7-10 \mathrm{~cm}$. longis et $1.3-2.5$ $\mathrm{cm}$. latis, venis undique elevatis, petiolo $3-5 \mathrm{~mm}$. longo glabro; floribus ignotis; fructibus globosis purpureis $4-5 \mathrm{~mm}$. longis, pedicello $3-4 \mathrm{~mm}$. longo glabro, bracteis parvis 2 sepaloideis, sepalis 5 glabris inaequalibus suborbicularibus ca. $1.5-2 \mathrm{~mm}$. longis et $1.5 \mathrm{~cm}$. latis, margine glandulosis, stylo tripartito ca. $2 \mathrm{~mm}$. longo.

Kwangsi: in woods, Seh-fing, Dar Shan, S. Nanning, alt. 750 m., R. C. Ching 8106 (NY, TYPE; SY), Oct. 21, 1928 (tree $30 \mathrm{ft}$. with gray bark; leaves thick, glossy green above, light green below; fruit oblongovate, dark purple).

The type of this species was identified formerly as $E$. nitida. There is a resemblance to this species. However, E. lanciformis resembles more closely $E$. japonica in that the leaves are slender-elongate and the leafmargin is undulate-serrate rather than sharply serrate as in most species of the genus. The lower third of the leaf-margin is nearly entire.

The unfolding leaf-buds are sparsely pubescent on the very young petioles. This is the only pubescence on the whole plant and this in turn becomes glabrescent before the leaves are mature. This pubescence would not be observed unless one should be looking for just this feature. Otherwise, it is a typical glabrous species with winged branchlets.

\section{Eurya Metcalfiana, spec. nov.}

Frutex humilis, ramulis glabris; foliis persistentibus coriaceis glabris ellipticis vel oblongo-ellipticis, $2.0-3.5 \mathrm{~cm}$. longis et $8-15 \mathrm{~mm}$. latis, basi cuneatis, apice breviter obtuse acuminatis, margine serrulatis, nervis utrinque 7-10, supra profunde impressis, subtus leviter elevatis, brevissime petiolatis, petiolis ca. $1 \mathrm{~mm}$. longis; floribus masculis in axillis foliorum solitariis (ex specimine) fragrantibus, pedicellis glabris $1-2 \mathrm{~mm}$. longis, bracteis 2 sepaloideis, sepalis 5 imbricatis glabris concavis obtusis inaequalibus ca. $3 \mathrm{~mm}$. longis et $2.5 \mathrm{~mm}$. latis, petalis 5 basi connatis albidis obtusis ca. $5 \mathrm{~mm}$. longis et $2-3 \mathrm{~mm}$. latis, staminibus 10 , fila- 
mentis $3 \mathrm{~mm}$. longis, antheris basi lobatis $1.5 \mathrm{~cm}$. longis, ovario rudimentario, floribus femineis ignotis; fructo immaturo globoso, stylo $0.25 \mathrm{~mm}$. longo.

Kwangtung: in thicket, Lo Hai Ngan Sam Kok Shan, Cheung Uk Village, Ts'ung-hwa (Tsung-fa) District, W. T. Tsang 24842 TYPE (woody $2 \mathrm{ft}$. high; flowers white, fragrant). ANHwEI: open rocky ridge, Whang Shan, S. Anhwei, alt. 1400 m., R. C. Ching 2992, July 13, 1925 (common low dense shrub with gray bark; leaves glossy green above, pale below) (AA, SY).- Yellow Mt., alt. 1800 m., M. Chen 1243, 1262, 1319 (SY).

Because of its deeply impressed nerves on the upper surface of the leaf this species resembles somewhat E. Fangii Rehder and E. cavinervis Vesque. However, E. Fangii is characterized by pubescence on the young leaves and branchlets, a more sharply acuminate leaf with sharper serrations. In E. Metcalfiana the leaf buds and young growth in general are strictly glabrous. Eurya cavinervis, although also strictly glabrous, is a much more robust species with larger leaves and is confined to India and Yunnan, while E. Fangii as far as known, is found only in Szechuan.

This species is named in honor of Prof. Franklin P. Metcalf of Lingnan University. Professor Metcalf has been associated with Chinese botany for over a decade and has contributed much to our knowledge of the flora of Fukien and Kwangtung.

Eurya obovata (Blume) Korthals in Temminck, Verh. Nat. Gesch. Bot. 3: 118. 1840.- - For further citations and synonymy see Kobuski in Ann. Missouri Bot. Gard. 25: 343. 1937.

Distribution: Celebes, Java (fide Korthals), Sumatra, Borneo.

Borneo. $\mathrm{M} \mathrm{t}$. K i n a b a lu : Upper Kinabalu, J. E $M$. $S$. Clemens 27833, 28990, 29881, 30347, 50813, 50879.

Eurya obovata (Blume) Korthals var. platyphylla, var. nov.

A specie typica differt foliis majoribus 5-9 cm. longis et $3.5-4 \mathrm{~cm}$. latis vel foliis $3.5-5.5 \mathrm{~cm}$. longis et $2-3.5 \mathrm{~cm}$. latis in speciminibus ad var typicam accedentibus.

British North Borneo. M o u $\mathrm{n} t \mathrm{~K}$ i n a ba l u : Hill thicket, Marai Parai, alt. 1500 m., J. E M. S. Clemens 32344 (Type), March 22-24, 1933.- Also J. E M. S. Clemens 30862, 32413, 35094, 40871, 40883, 50009, 50298, at 1200-1800 m. alt.; 29800, 33108, 33946, 50621, $50986,50989,55093$ at $2400-2750 \mathrm{~m}$. alt.

On examining material collected by J. \& M. S. Clemens on Mt. Kina- 
balu, British North Borneo, one is bewildered by the fact that the field numbers and dates of collection lack correlation. Higher numbers have often been given to material collected at an earlier date than the low number. Also, accurate altitude records have not been recorded on all labels. This last may be due to copying the label, since on the only original field label seen, the altitude has been recorded.

For this species and its variety, nearly twenty-five specimens were obtained from Mt. Kinabalu, and if there was a reasonable correlation between date, number and altitude, one might be able to show with confidence a fine series of gradation from the small-leaved E. obovata to the large-leaved variety E. obovata var. platyphylla. As it is, the series must be filled in with material labeled merely "alt. 6000-13500 ft."

Even so, the species itself is found to occur at an altitude of about $3300 \mathrm{~m}$. and is characterized by small coriaceous leaves, $1.5-3 \mathrm{~cm}$. long, $1-1.5-2 \mathrm{~cm}$. wide with the veins deeply impressed on the upper surface and raised on the lower surface. At the other extreme and at an altitude of $1200-1800 \mathrm{~m}$. is found the large-leaved variety here described. This is characterized by leaves $5-9 \mathrm{~cm}$. long and $3.5-4 \mathrm{~cm}$. wide with veins distinctly raised on both surfaces.

Examining only the diverse material mentioned above, one would not hesitate separating the two as widely distinct species. However, at an altitude of $2400-2750 \mathrm{~m}$. is found an intermediate stage with leaves $3.5-5 \mathrm{~cm}$. long and $2-3.5 \mathrm{~cm}$. wide. Some leaves have impressed veins on the upper surface while others have raised veins such as are found on the large-leaved specimens, and still others have raised veins with impressed channels. Examples of the diverse venation can be found on a single branchlet.

Rather than designate two varieties, one for the large-leaved and one for the intermediate stage, I am including both under the single variety described above.

Eurya pahangensis, spec. nov.

Frutex [vel arbor ?], ramulis cinereo-brunneis teretibus pubescentibus asperatis; foliis subcoriaceis oblongo-ovatis $5-7.5 \mathrm{~cm}$. longis et $1.5-2.5$ $\mathrm{cm}$. latis pubescentibus, supra nitidis, basi cuneatis, apice acuminatis, margine serrulatis, venis utrinque elevatis, petiolis ca. $2 \mathrm{~mm}$. longis pubescentibus; floribus femineis axillaribus 2-3, pedicellis ca. $2 \mathrm{~mm}$. longis pubescentibus, bracteis 2 pubescentibus sepaloideis, sepalis 5 imbricatis inaequalibus suborbicularibus ca. $1.5 \mathrm{~mm}$. longis, petalis $5 \mathrm{ca}$. $2.5 \mathrm{~mm}$. longis et $1.5 \mathrm{~mm}$. latis, apice obtusis, basi connatis, ovario subgloboso dense cano-pubescente, stylo ad medium 4- vel 5- fido; fructibus ignotis. 
Federated Malay States: Pahang, Fraser's Hill, E. J. H. Corner (Singapore Field Number 33241), August 19, 1937.

This species is characterized by a dense hoary pubescence on the ovary, 4-5-fid style and rough, pubescent, terete, gray branchlets. Eurya trichocarpa, its nearest relative, has a sparse pubescence confined almost solely to the terminal bud, 3-fid style and smooth, shining, almost glabrous reddish branchlets.

Eurya paratetragonoclada $\mathrm{Hu}$ in Bull. Fan Mem. Inst. Biol., Bot. Ser. 8: 149. 1938.

Southwestern Yunnan: in forest, Che-tse-lo, alt. 3200 m., H. T. Tsai 58438, isotype, Sept. 8, 1937 (tree $4 \mathrm{~m}$. with blue fruit).

In his description of this species, $\mathrm{Hu}$ refers repeatedly to the pubescence. In the genus Eurya, the terminal bud is rather a good criterion of the general glabrous or pubescent condition of the whole plant. In this species, the isotype shows the terminal bud to be strictly glabrous and I fail to find any pubescence on either surface of the leaves. The mere fact that the young branchlets are angled would lead one to infer that the plant would be glabrous since these two characteristics usually go together. $\mathrm{Hu}$ also refers to the sepals and fruit as "with scattered hairs." Unfortunately, my isotype is sterile so that I can merely conjecture that these also might be glabrous.

In the English description the internodes are said to be " 7 to $1.5 \mathrm{~mm}$. long." This should read 7 to $15 \mathrm{~mm}$. long.

Eurya pentastyla, spec. nov.

Frutex [vel arbor ?], ramulis rubro-brunneis, innovationibus pubescentibus, alatis pubescentibus secundum alas axillasque ceterum glabris; foliis coriaceis glabris oblongo-ovatis $6.5-8.5 \mathrm{~cm}$. longis et $1.5-2.3 \mathrm{~cm}$. latis, basi cuneatis, apice acuminatis, venis obscuris utrinque elevatis, margine subundulato-serratis minutissime glandulosis, petiolis ca. $2 \mathrm{~mm}$. longis; floribus ignotis; fructibus axillaribus 3 glabris globosis ca. 4-5 $\mathrm{mm}$. longis, pedicellis glabris $3 \mathrm{~mm}$. longis, bracteis 2 distinctis sepaloideis, sepalis 5 imbricatis glabris subrotundatis inaequalibus $1.5-2 \mathrm{~mm}$. longis et ca. $1.5 \mathrm{~mm}$. latis, stylo ad trientem inferiorem 5-partito, $3 \mathrm{~mm}$. longo.

Sumatra: vicinity of Tomoean Dolok, Asahan, alt. 1000 m., Rahmat Si Boeea 9027, type, June 10-15, 1936.- Same locality, Rahmat Si Boeea 9076, June 10-15, 1936.- The summit, Tor Matoetoeng, Asahan, alt. 1792 m., Rahmat Si Boeea 9417, July 10-15, 1936.

This Sumatran species is characterized by 5 -parted styles, pubescent 
leaf-buds and winged stems with a fine pubescence in the angle of the wings, and glabrous fruit, in so far as one can be sure from an examination of a mature fruiting specimen.

Unusual is the combination of pubescent leaf-buds and winged stems, as is the pubescence in the angles of the wings. Generally one associates winged stems in Eurya with strict glabrity.

The nearest relative is Malayan-Chinese E. trichocarpa Korthals. This latter species has a 3-parted style, pubescent leaf-buds with terete stems and pubescent ovary which in fruit becomes glabrescent. This glabrescent condition may be found to apply to $E$. pentastyla when flowering specimens can be examined.

Eurya pittosporifolia $\mathrm{Hu}$ in Bull. Fan Mem. Inst. Biol., Bot. Ser. 8: 150. 1938.

Southwestern Yunnan: in dense forest, Che-li-Hsien, Dah-MengLung, Meng-Soong, alt. 2000 m., C. W. Wang 78362 (Isotype AA), Sept. 1936 (common tree 6 m.).

The pubescent ovary and 5-parted styles are excellent distinguishing features of the species. The styles are $3 \mathrm{~mm}$. long and distinct rather than connate. Other significant diagnostic characters are the puberulent terminal buds covered with dense white pubescence and the glabrous, long-acuminate leaves.

Eurya quinquelocularis, spec. nov.

Arbor 3-10 m., ramulis cinereo-brunneis teretibus pubescentibus; foliis membranaceis oblongo-ovatis $7-15 \mathrm{~cm}$. longis et $2-4 \mathrm{~cm}$. latis, subtus leviter pubescentibus, basi cuneatis, apice acuminatis, venis supra impressis, subtus elevatis, margine serrulatis, petiolis $2-3 \mathrm{~mm}$. longis; floribus femineis 5-6 axillaribus, pedicellis pubescentibus $6 \mathrm{~mm}$. longis, bracteis $2 \mathrm{ca} .1 \mathrm{~mm}$. longis pubescentibus sepaloideis, sepalis 5 imbricatis pubescentibus inaequalibus concavis, $2-2.5 \mathrm{~mm}$. longis et ca. $2 \mathrm{~mm}$. lat is orbicularibus, petalis 5 orbicularibus $3 \mathrm{~mm}$. longis $1.5 \mathrm{~mm}$. latis basi connatis $1 \mathrm{~mm}$., ovario globoso glabro 5-loculari, stylo $3-3.5 \mathrm{~mm}$. longo, 5-partito, basi connato $1 \mathrm{~mm}$.; floribus masculis ignotis; fructibus globosis quinquelocularibus $6 \mathrm{~mm}$. latis nigrescentibus.

Kwangsi: in woods, Chu Feng Sha, 30 li southwest of Shan Fang, N. Luchen, alt. 600 m., R. C. Ching 5794 (тype AA; Isotype NY, SY), June 7, 1928 (tree $30 \mathrm{ft}$. [diameter $1 \mathrm{ft}$.] with gray bark; leaves lustrous green above, pale below; fruit green turning to black).- Shap Man Taai Shan, Nam She Village, southeast of Shang-sze, Kwangtung Border (Shang-sze District), W. T. Tsang 24560, 24753, Oct. 22 - Nov. 26, 
1934.- Precise locality and date of collection lacking, C. Wang 39002, 39941. - Midway up mountain side, Pingnan, Lo Huo'ng, Iu Shan, Kwangsi Museum 200, Jan. 13, 1924 (shrub 5-6 ft. with brown bark) (SY).- Hillside in woods, at foot of mountain, Pingnan, Kwangsi Museum 760, Dec. 25, 1923 (shrub 5-6 ft. with brown bark) (SY). Yunnan: in forest, Mengtse, alt. 1525 m., A. Henry 10372 (tree $10 \mathrm{ft}$. with yellowish flowers) (AA, SY).

This species is characterized by a 5-celled fruit and 5-parted style, membranaceous leaves with impressed veins on the upper and raised veins on the lower surface. Long pedicels $(6 \mathrm{~mm}$.) cause the flowers and fruit to stand out from the stem.

This species should not be confused with E. pentastyla Kobuski of Sumatra. The only relationship of note is the 5-styled condition of flower and fruit. The nearest relative is perhaps E. cerasifolia (D. Don) Kobuski from which it can easily be separated by the 5 -styled flowers and fruit mentioned above.

Eurya rugosa Hu in Bull. Fan Mem. Inst. Biol., Bot. Ser. 8: 151. 1938.

Western Szechuan: in thickets, Ping-Shan Hsien, alt. 1600 m., F. T. Wang 22685, Isotype, April 16, 1931 (shrub).

This species is very distinct and is characterized by thick rugose leaves with impressed venation on both surfaces. The venation character separates it quickly from $E$. dasyclados Kobuski which possesses raised venation on both surfaces. Also in the latter species the fruit is glabrous while E. rugosa has fruit which is minutely pilosulose soon becoming glabrescent.

$\mathrm{Hu}$ says that the young branchlets are "terete ferruginous-villosulose, striate, more or less winged and glabrescent in age." This so-called winged condition, although very slight, is unusual on a species as distinctly pubescent as E. rugosa. Generally speaking, the species seems to be glabrescent after the first year's growth. In E. dasyclados the branchlets are densely pilose on the second and third year's growth.

Eurya rugosa, according to $\mathrm{Hu}$, possesses styles which are two-parted and adnate at the base. All the styles examined on the isotype deposited at the Arnold Arboretum are three-parted and split to the base. Occasionally some appear two-parted but a closer examination shows that the third-part has been broken off near the base.

Eurya subintegra, spec. nov.

Frutex, ramulis alatis glabris rubro-brunneis; foliis coriaceis glabris, ad $10 \mathrm{~cm}$. longis et $3.5 \mathrm{~cm}$. latis, acuminatis, basi cuneatis, margine 
integris vel subintegris raro crenulato-serrulatis, venis undique leviter elevatis, petiolis ca. $1 \mathrm{~cm}$. longis; floribus ignotis; fructibus immaturis ovatis, pedicellis $4-5 \mathrm{~cm}$. longis glabris, bracteis sepaloideis, sepalis 5 glabris inaequalibus ca. $1.5-2 \mathrm{~mm}$. longis et $2.5 \mathrm{~mm}$. latis, stylo ca. $1.5-2 \mathrm{~mm}$. longo tripartito.

Kwangsi: Taai Ip Wong Ming Shue, Shap Man Taai Shan, near Iu Shan village, s.e. of Shang-sze, Kwangtung Border (Shang-sze District), fairly common in silt and swamp, W. T. Tsang 22212 TYPE, May 5, 1933, (scattered shrubs, $1 \mathrm{~m}$.; fruit dark blue).- Shap Man Taai Shan, near Iu Shan village, s.e. of Shang-sze, Kwangtung Border (Shang-sze District), abundant in clay soil, W. T. Tsang 22256, May 10, 1933 ( $3.5 \mathrm{~m}$. high; fruit dark blue).

The entire or nearly entire leaves of this species recall to mind $E$. Macartneyi Champion. However, in E. Macartneyi, the stems are terete even though the species is strictly glabrous, an unusual combination of characters in the genus. In E. subintegra the winged or angled stem accompanies the glabrous condition of the whole specimen.

There are slight differences between the two specimens cited, but these do not appear sufficiently important to separate the two specifically. In Tsang 22256, the leaf is larger $(13 \mathrm{~cm} . \times 4 \mathrm{~cm}$.), obovate and tapers to a longer point. Unfortunately, in this specimen the styles are broken off at the point of articulation making it difficult to estimate their length. In Tsang 22212, the type, the young branchlets are definitely alate whereas in Tsang 22256 , the young branchlets are only angled.

Herbarium, Arnold Arboretum, Harvard University. 


\section{$2 \mathrm{BHL}$ Biodiversity Heritage Library}

Kobuski, Clarence E. 1939. "Studies in Theaceae. IV. New and Noteworthy Species of Eurya." Journal of the Arnold Arboretum 20(3), 361-374. https://doi.org/10.5962/p.325786.

View This Item Online: $\underline{\text { https://www.biodiversitylibrary.org/item/33596 }}$

DOI: https://doi.org/10.5962/p.325786

Permalink: https://www.biodiversitylibrary.org/partpdf/325786

\section{Holding Institution}

Missouri Botanical Garden, Peter H. Raven Library

\section{Sponsored by}

Missouri Botanical Garden

\section{Copyright \& Reuse}

Copyright Status: In copyright. Digitized with the permission of the rights holder.

Rights Holder: Arnold Arboretum of Harvard University

License: http://creativecommons.org/licenses/by-nc-sa/3.0/

Rights: https://biodiversitylibrary.org/permissions

This document was created from content at the Biodiversity Heritage Library, the world's largest open access digital library for biodiversity literature and archives. Visit BHL at https://www.biodiversitylibrary.org. 